\title{
Role and clinical utility of pramipexole extended release in the treatment of early Parkinson's disease
}

This article was published in the following Dove Press journal:

Clinical Interventions in Aging

14 March 2012

Number of times this article has been viewed

\section{Eva-Maria Hametner \\ Klaus Seppi \\ Werner Poewe}

Department of Neurology, Innsbruck Medical University, Innsbruck, Austria
Correspondence: Werner Poewe Department of Neurology, Innsbruck Medical University, Anichstraße 35,

A-6020 Innsbruck, Austria

Tel +435I2504 23850

$\mathrm{Fax}+4351250423852$

Email werner.poewe@i-med.ac.at

\begin{abstract}
The aim of this article is to provide a short review of the most relevant pharmacological and clinical data on pramipexole extended release (ER) as well as to address the clinical utility and potential advantages of a once-daily formulation especially in the treatment of early Parkinson's disease (PD). Pramipexole is widely established as a symptomatic treatment in early as well as advanced PD. The development of an ER formulation, with stable pramipexole plasma concentration over 24 hours, now offers a bioequivalent once-daily alternative. Double-blind randomized controlled trials in early and advanced PD, have established noninferiority of pramipexole ER compared with immediate release as well as superiority of both formulations over placebo. The overnight switch from the standard to the once-daily formulation was shown to be successful in $>80 \%$ of patients without requiring any dose adjustments. Potential benefits of the prolonged-release design, which have not yet been formally demonstrated in the pivotal trial program, include improved compliance and a potential for better symptomatic control, particularly in patients with early disease that can be managed with monotherapy.
\end{abstract}

Keywords: pramipexole, Parkinson's disease, extended release, compliance, control

\section{Role of dopamine agonists in the treatment of Parkinson's disease}

Although levodopa (LD) still remains the gold standard for symptomatic efficacy in reducing the motor symptoms of Parkinson's disease (PD), ${ }^{1}$ its long-term use is associated with the development of potentially disabling motor complications, including response oscillations as well as drug-induced dyskinesias (LD-induced dyskinesias), affecting approximately $30 \%$ of patients after only 2 years of LD exposure. ${ }^{2}$ The precise underlying pathophysiology of LD-induced motor complications is still incompletely understood; however, it is believed that pulsatile dopamine-receptor stimulation, leading to neuroplastic changes in the basal ganglia circuitry, plays a pivotal role. ${ }^{1,3-5}$ Dopamine agonists (DAs) act directly on striatal dopamine receptors, with preferential effects on the D2 over D1 subfamily, and generally have considerably longer half-lives than LD (Table 1). ${ }^{6}$ While the first agents of this class were ergolinic compounds with affinities to multiple non-DA-receptor types, the newer agents are nonergolinic and seem to lack the risk for cardiovalvular fibrosis, recently reported for ergolinic agonists, ${ }^{7}$ which have since been withdrawn from many markets. In clinical trials involving patients with early PD, initial monotherapy with DAs was consistently associated with a significantly reduced risk of motor complications compared with LD, over double-blind follow-up periods of up to 5 years (Table 2), ${ }^{8-10}$ such that DAs are currently recommended as first-line therapies particularly for patients with younger age at onset. ${ }^{11,12}$ In addition, 
Table I Pharmacological properties of dopamine agonists

\begin{tabular}{|c|c|c|c|c|c|}
\hline & $\begin{array}{l}\text { D2/D3 } \\
\text { receptor affinity }\end{array}$ & $\begin{array}{l}\text { DI } \\
\text { receptor affinity }\end{array}$ & $\begin{array}{l}\text { NE } \\
\text { receptor affinity }\end{array}$ & $\begin{array}{l}5-\mathrm{HT}_{2 \mathrm{~B}} \\
\text { receptor affinity }\end{array}$ & Half-life (h) \\
\hline \multicolumn{6}{|l|}{ Ergot agonists } \\
\hline Bromocriptine & D2 & - & + & $+1-$ & $3-6$ \\
\hline Cabergoline & $\mathrm{D} 3>\mathrm{D} 2$ & - & + & + & 65 \\
\hline Dihydroergocriptine & D2 & $+1-$ & + & + & $12-16$ \\
\hline Lisuride & D2 & - & + & $t^{\mathrm{a}}$ & $2-3$ \\
\hline Pergolide & $\mathrm{D} 3>\mathrm{D} 2$ & + & + & + & $15-20$ \\
\hline \multicolumn{6}{|l|}{ Non-ergot agonists } \\
\hline Apomorphine & $\mathrm{D} 3>\mathrm{D} 2$ & + & - & - & $0-5$ \\
\hline Piribedil & $\mathrm{D} 3>\mathrm{D} 2$ & - & $+1-$ & - & 20 \\
\hline Pramipexole & $\mathrm{D} 3>\mathrm{D} 2$ & - & $+1-$ & - & 10 \\
\hline Ropinirole & $\mathrm{D} 3>\mathrm{D} 2$ & - & - & - & 6 \\
\hline Rotigotine & $\mathrm{D} 3>\mathrm{D} 2$ & + & - & - & $5-7^{b}$ \\
\hline
\end{tabular}

Notes: -, no affinity; +, high affinity; +/-, moderate affinity. ${ }^{\text {AAntagonist; }}$ 'after transdermal application.

Copyright (C) 2009, Elsevier. Modified with permission from Antonini A, Tolosa E, Mizuno Y, et al. A reassessment of risks and benefits of dopamine agonists in PD. Lancet Neurol. 2009;8:929-937. ${ }^{6}$

Abbreviation: NE, norepinephrine.

DAs are established first-line therapies to reduce motor fluctuations in LD-treated patients. ${ }^{11,12}$ Both types of clinical benefit from DAs are likely to be related to their longer half-life, resulting in more continuous striatal DA-receptor stimulation. Continuous 24-hour delivery with once-daily dosing has become possible with a transdermal formulation of the short half-life agonist rotigotine and, recently, novel extended-release (ER) formulations have been developed for the nonergolinic oral compounds ropinirole and pramipexole. The latter principle is likely to increase convenience and possibly adherence, particularly for patients with early disease that can be managed with monotherapy.

\section{Pharmacology and pharmacokinetics of pramipexole ER}

Pramipexole is a full intrinsic DA with a nonergot structure. The aminobenzothiazole compound is highly selective for the D2 receptor family and, intragroup, has preferential affinity for the D3 receptor subtype. ${ }^{13}$ The agent lacks affinity for dopamine receptors D1 and D5 and displays only little affinity for D2 and D4 receptor subtypes. ${ }^{14}$ Pramipexole ER was designed as a prolonged-release tablet with pramipexole dihydrochloride monohydrate dispersed homogeneously throughout the matrix. The active substance is released proportional to the square-root of time ${ }^{15}$ by two different mechanisms: diffusion and erosion, ${ }^{15}$ reaching its maximum plasma concentration $\left(\mathrm{C}_{\max }\right)$ approximately 6 hours after oral administration (immediate release [IR]: $\mathrm{C}_{\max } 1-3$ hours). In other respects the pharmacokinetic profile mostly coincides with the well-known IR formulation. Following oral administration, the agent shows a bioavailability of $>90 \% .{ }^{15}$ In fact, pharmacokinetic studies observed an increase in $\mathrm{C}_{\max }$ with concomitant intake of a high-fat meal (24\% after a single dose administration and about $20 \%$ after multiple dose administrations), but there was no significant change in overall area under the curve $\left(\mathrm{AUC}_{0-24 \text { hours }}\right) .{ }^{15,16}$ Protein binding is $<20 \%$ and the agent is metabolized only to a small extent and predominantly eliminated by renal excretion $(\sim 90 \%)$. With a renal clearance of approximately $400 \mathrm{~mL} /$ min, the elimination half-life $\left(t^{1} / 2\right)$ varies from 8 hours in the young to 12 hours in the elderly. Pramipexole ER is available in five dosage strengths $(0.26[0.375] \mathrm{mg}, 0.52[0.75] \mathrm{mg}$, 1.05 [1.5] mg, 2.1 [3] mg, and 3.15 [4.5] mg [all doses are

Table 2 Results of the main trials of levodopa versus dopamine agonists in early Parkinson's disease

\begin{tabular}{|c|c|c|c|c|c|c|c|c|}
\hline & \multirow[t]{2}{*}{$\begin{array}{l}\text { Number on LD } \\
\text { (agonist) }\end{array}$} & \multirow[t]{2}{*}{$\begin{array}{l}\text { Duration } \\
\text { (years) }\end{array}$} & \multicolumn{2}{|c|}{$\begin{array}{l}\Delta \text { UPDRS part III } \\
\text { score }\end{array}$} & \multicolumn{2}{|c|}{$\begin{array}{l}\text { Dyskinesia } \\
\text { (\% of patients) }\end{array}$} & \multicolumn{2}{|c|}{$\begin{array}{l}\text { Wearing-off } \\
\text { (\% of patients) }\end{array}$} \\
\hline & & & Levodopa & Agonist & Levodopa & Agonist & Levodopa & Agonist \\
\hline LD versus ropinirole ${ }^{8}$ & 89 (I79) & 5 & $-4.8 \pm 8.3$ & $-0.8 \pm 10.1$ & 45 & 20 & 34 & 23 \\
\hline LD versus pramipexole ${ }^{9}$ & $|5|(150)$ & 2 & $-7.3 \pm 8.6$ & $-3.4 \pm 8.6$ & 30.7 & 9.9 & 38.0 & 23.8 \\
\hline LD versus pergolide $^{10}$ & 146 (|48) & 3 & $-2.8 \pm 7.8$ & $2.8 \pm 9.8$ & 26.0 & 8.2 & 43.8 & 30.6 \\
\hline
\end{tabular}

Notes: $\triangle$ UPDRS, change in unified Parkinson's disease rating scale. *Frequency of motor complications (fluctuations plus dyskinesia).

Copyright $\odot 2009$, Elsevier. Modified with permission from Antonini A, Tolosa E, Mizuno Y, et al. A reassessment of risks and benefits of dopamine agonists in PD. Lancet Neurol. 2009;8:929-937. ${ }^{6}$

Abbreviations: LD, levodopa; UPDRS, unified parkinson's disease rating scale. 
expressed in terms of pramipexole base; corresponding dose strengths of pramipexole salt are given in brackets]) and is approved for use in early PD as well as adjunct therapy in advanced PD with motor complications.

\section{Clinical efficacy in early PD}

Two large randomized double-blind placebo-controlled Phase III trials were conducted to evaluate the clinical efficacy of pramipexole ER in early PD patients. ${ }^{17,18}$ These are summarized as follows.

Two hundred and fifty-nine patients with early PD at Hoehn and Yahr stage 1 to 3, diagnosed within the preceding 5 years, were randomized (2:2:1) to receive pramipexole ER (0.26-3.15 [0.375-4.5] mg qd), pramipexole IR (0.088-1.1 [0.125-1.5] mg tid), or placebo. Following a 7-week-flexible up-titration phase, drug doses were maintained for an additional 26 weeks, during which, to maximize patient retention in the trial, open-label LD rescue medication was permitted for subjects experiencing insufficient control of parkinsonism. Post-LD-rescue data were censored for the primary analysis. At 18 weeks an interim analysis on a subset of 253 patients was planned to evaluate superiority of efficacy of pramipexole ER to placebo on the Unified Parkinson's Disease Rating Scale (UPDRS) II + III (primary endpoint). ${ }^{18}$ At 33 weeks, the study aimed to demonstrate noninferiority of pramipexole ER to pramipexole IR in the combined score on UPDRS II + III (primary endpoint). ${ }^{17}$ Noninferiority was predefined as a treatment-group difference for which the lower bound of the $95 \%$ confidence interval (CI) did not exceed -3 points. This margin had been chosen conservatively to be well outside the minimally clinically relevant difference on the UPDRS, which has been suggested to be -7 points for parts II and III combined. ${ }^{19}$ At 18 weeks, the adjusted mean change in UPDRS II + III combined scores, censoring
post-LD-rescue data, was -7.4 (1.1) in the pramipexole ER group, compared with -2.7 (1.3) in the placebo group $(P=0.0010$ vs placebo) and $-7.5(1.1)$ in the pramipexole IR group $\left(P=0.0006\right.$ vs placebo) ${ }^{18}$ Including data from subjects receiving LD rescue medication, the adjusted mean change was -5.1 (1.3) for placebo, -8.1 (1.1) for pramipexole ER ( $P=0.0282$ vs placebo), and -8.4 (1.1) for pramipexole IR $(P=0.0153$ vs placebo $) .{ }^{18}$ Hence, using either approach, a statistically significant difference between pramipexole groups and placebo could be demonstrated from week 4 onward (ER $P=0.0111$, IR $P=0.0042$ vs placebo at week 4 by either approach). ${ }^{18}$ At 33 weeks, UPDRS II + III change - censoring post-LD-rescue data - was -8.2 for ER and -8.7 for IR. The resultant treatment difference was $-0.5(95 \% \mathrm{CI}:-2.3$ to +1.3$)$, thereby establishing noninferiority of the ER formulation. Including LD-rescue data, the adjusted mean decrease was -8.5 versus -9.4 , revealing a difference of $-0.9(95 \% \mathrm{CI}:-2.7,+0.9)$, which is still well within the predefined margin. ${ }^{17}$ As already demonstrated at 18 weeks, the 33-week analysis confirmed the superiority of pramipexole ER over placebo (adjusted mean change in UPDRS II + III score: -8.2 ER vs -1.2 placebo $[P<0.0001]) .{ }^{17}$ Consistent with the symptomatic efficacy of pramipexole, fewer patients on active treatment required LD-rescue medication (7.0\% ER, 4.3\% IR, 21.4\% placebo). ${ }^{17}$ Superiority of both pramipexole formulations could also be shown for secondary outcome measures, including Global Impression of Improvement responder rates (41.4\% ER, 45.1\% IR vs $20.6 \%$ placebo [ $P=0.0003$ and $P<0.0001]$ ), Patient Global Impression of Improvement responder rates $(34.4 \% \mathrm{ER}$, $32.4 \%$ IR vs $16.5 \%$ placebo $[P=0.0008$ and $P=0.0020])$, and UPDRS II + III responder rates $(66.7 \% \mathrm{ER}, 63.8 \%$ IR vs $35.0 \%$ placebo $[P<0.0001]) .{ }^{17}$ A summary of the primary and key secondary endpoints at week 33 is given in Table 3 .

Table 3 Efficacy results at week 33 (FAS/LOCF with levodopa rescue censored)

\begin{tabular}{|c|c|c|c|}
\hline & $\begin{array}{l}\text { Placebo } \\
(n=103)\end{array}$ & $\begin{array}{l}\text { Pramipexole ER } \\
(n=2 \mid 3)\end{array}$ & $\begin{array}{l}\text { Pramipexole IR } \\
(n=207)\end{array}$ \\
\hline \multicolumn{4}{|l|}{ Primary endpoint } \\
\hline UPDRS II + III score, adjusted mean change $(95 \% \mathrm{CI})$ & -1.2 & -8.2 & -8.7 \\
\hline \multirow[t]{2}{*}{$(P$ versus placebo, ANCOVA) } & $(-3.1$ to 0.6$)$ & $(-9.5$ to -6.9$)$ & $(-10.1$ to -7.4$)$ \\
\hline & & $(<0.0001)$ & $(<0.0001)$ \\
\hline \multicolumn{4}{|l|}{ Key secondary endpoints } \\
\hline \multirow[t]{2}{*}{ CGI-I scale responder rate, \% ( $P$ versus placebo, $C M H)^{a}$} & 20.6 & 41.4 & 45.1 \\
\hline & & $(0.0003)$ & $(<0.0001)$ \\
\hline \multirow[t]{2}{*}{ PGI-I scale responder rate, \% (P versus placebo, $\mathrm{CMH})^{\mathrm{b}}$} & 16.5 & 34.4 & 32.4 \\
\hline & & $(0.0008)$ & $(0.0020)$ \\
\hline
\end{tabular}

Notes: aProportion of patients classified as either much or very much improved; broportion of patients self-classified as either much or very much better.

Copyright (C) 201I, Wolters Kluwer Health. Modified with permission from Poewe W, Rascol O, Barone P, et al. Extended-release pramipexole in early Parkinson disease: A 33-week randomized controlled trial. Neurology. 2011;77(8):759-766. ${ }^{17}$

Abbreviations: FAS, full analysis set; LOCF, last observation carried forward; ER, extended release; IR, immediate release; CMH, Cochran-Mantel-Haenszel test; ANCOVA, analysis of covariance. 
Table 4 Rates of successful switching after 9 weeks

\begin{tabular}{llll}
\hline Time point & $\begin{array}{l}\text { Successfully } \\
\text { switched to } \\
\text { DB ER }\end{array}$ & $\begin{array}{l}\text { Successfully } \\
\text { switched to } \\
\text { DB IR }\end{array}$ & $\begin{array}{l}\text { CMH } \\
\text { P-value, } \\
\text { ER versus IR }\end{array}$ \\
\hline 4 weeks & $84 / 103(81.6 \%)$ & $48 / 52(92.3 \%)$ & 0.0803 \\
9 weeks & $87 / 103(84.5 \%)$ & $49 / 52(94.2 \%)$ & 0.0790 \\
\hline
\end{tabular}

Copyright $\odot$ 2010, John Wiley and Sons. Modified with permission from Rascol O, Barone P, Hauser RA, et al. Efficacy, safety, and tolerability of overnight switching from immediate- to once daily extended-release pramipexole in early Parkinson's disease. Mov Disord. 2010;25(14):2326-2332. ${ }^{20}$

Abbreviations: DB, double blind; ER, extended release; IR, immediate release; $\mathrm{CMH}$, Cochran-Mantel-Haenszel test.

\section{Switch study}

Rascol et al conducted a randomized, double-blind, doubledummy, parallel-group study to assess efficacy, safety, and tolerability of an overnight switch from pramipexole IR to ER in early PD patients. ${ }^{20}$ After a 2-4-week open-label run-in on pramipexole IR tid, 156 patients were switched overnight either to ER or to IR at an unchanged daily dosage (randomized 2:1). Subjects were allowed a one-step dose adjustment as required for efficacy and/or tolerability 4 and 5 weeks after switching. Dosage levels then had to remain stable for another 4 weeks. The primary efficacy endpoint was defined as the proportion of patients successfully switched (with or without any dosage adjustment) at the end of week 9, determined as no worsening from baseline UPDRS II + III score $>15 \%$ and no withdrawal due to drug-related adverse events (AEs). Noninferiority was predefined as a $95 \%$ CI with a lower bound not exceeding $-15 \%$. At week $9,84.5 \%$ of patients in the ER versus $94.2 \%$ in the IR group were considered successfully switched (Table 4). The absolute difference between groups was $-9.76 \%$ (95\% CI: $-18.81 \%,+1.66 \%)$, hence noninferiority of pramipexole ER was not formally demonstrated. However, after 9 weeks, $80.6 \%$ of ER and $84.6 \%$ of IR recipients were successfully switched without requiring any dose adjustments. In the ER group, 16.5\% had increased and 2.9\% had decreased their dosage, while corresponding percentages in the IR group were $13.5 \%$ versus $1.9 \%$ (Table 5). The between-group difference for increased versus unchanged/decreased dosage was not significant $(P=0.6190)$. The mean pramipexole dosage at 9 weeks was $2.75( \pm 0.95) \mathrm{mg} /$ day $(+0.12 \mathrm{mg} /$ day from baseline) in the ER, compared with $2.83( \pm 0.86) \mathrm{mg} /$ day $(+0.09 \mathrm{mg} /$ day from baseline $)$ in the IR group.

\section{Safety and tolerability}

Pooled safety data of the clinical trials in early and advanced PD, comprising information from 803 PD patients exposed to clinically effective doses of pramipexole ER, show a slightly higher rate of AEs for both pramipexole IR and ER compared with placebo. However, no significant difference in AE profiles has been found between the two pramipexole formulations. A summary of the most common side effects is given in Table $6 .{ }^{15}$ Safety evaluation of the 33-week trial in early $\mathrm{PD}^{17}$ also identified somnolence, gastrointestinal complaints, and dizziness as the most frequent AEs. In this study, a small numerical increase in Epworth Sleepiness Scale score was observed in both pramipexole groups but mean values remained below the cut-off for excessive daytime sleepiness $(\leq 10)$. Impulse control disorders were also slightly more common in both active treatment groups (four patients in the ER, three in the IR, and one in the placebo group). Taken as a whole, pramipexole ER showed the same safety and tolerability profile as pramipexole IR.

\section{Patient-focused perspectives}

Poor compliance has been identified as a major issue in several disease areas ${ }^{21-24}$ including PD. ${ }^{25,26}$ The irregular intake of prescribed medication affects health care on many levels, including poor symptom control and reduced quality of life, ${ }^{27}$

Table 5 Dosage change from baseline to 9 weeks

\begin{tabular}{|c|c|c|c|c|c|c|}
\hline & \multicolumn{3}{|c|}{ Switched to DB ER } & \multicolumn{3}{|c|}{ Switched to DB IR } \\
\hline & $\begin{array}{l}\text { Dosage } \\
\text { increased }\end{array}$ & $\begin{array}{l}\text { Dosage } \\
\text { unchanged }\end{array}$ & $\begin{array}{l}\text { Dosage } \\
\text { decreased }\end{array}$ & $\begin{array}{l}\text { Dosage } \\
\text { increased }\end{array}$ & $\begin{array}{l}\text { Dosage } \\
\text { unchanged }\end{array}$ & $\begin{array}{l}\text { Dosage } \\
\text { decreased }\end{array}$ \\
\hline \multirow[t]{2}{*}{ Entire treatment group } & $17 / 103$ & $83 / 103$ & $3 / 103$ & $7 / 52$ & $44 / 52$ & $1 / 52$ \\
\hline & $(16.5 \%)$ & $(80.6 \%)$ & $(2.9 \%)$ & (13.5\%) & (84.6\%) & $(1.9 \%)$ \\
\hline \multirow[t]{2}{*}{ Successfully switched } & $12 / 87$ & $72 / 87$ & $3 / 87$ & $6 / 49$ & $42 / 49$ & $1 / 49$ \\
\hline & $(13.8 \%)$ & $(82.8 \%)$ & $(3.4 \%)$ & $(12.2 \%)$ & $(85.7 \%)$ & $(2.0 \%)$ \\
\hline Not & $5 / 16$ & $11 / 16$ & $0 / 16$ & $1 / 3$ & $2 / 3$ & $0 / 3$ \\
\hline successfully switched & $(31.3 \%)$ & $(68.8 \%)$ & $(0.0 \%)$ & $(33.3 \%)$ & $(66.7 \%)$ & $(0.0 \%)$ \\
\hline
\end{tabular}

Copyright (C) 2010, John Wiley and Sons. Modified with permission from Rascol O, Barone P, Hauser RA, et al. Efficacy, safety, and tolerability of overnight switching from immediate- to once daily extended-release pramipexole in early Parkinson's disease. Mov Disord. 2010;25(I4):2326-2332.20

Abbreviations: DB, double blind; ER, extended release; IR, immediate release. 
Table 6 Frequency of adverse events (\%)

\begin{tabular}{llll}
\hline & Pramipexole ER & Pramipexole IR & Placebo \\
\hline Somnolence & 20.5 & 21.4 & 12.7 \\
Nausea & 15.2 & 15.0 & 6.6 \\
Constipation & 10.5 & 10.9 & 3.6 \\
Dyskinesia & 9.5 & 8.6 & 3.6 \\
Dizziness & 6.2 & 12.7 & 6.6 \\
Hallucinations & 4.3 & 5.9 & 0.6 \\
Vomiting & 2.4 & 5.0 & 1.8 \\
\hline
\end{tabular}

Note: Assessment Report for Sifrol. EMEA/703892/2009. ${ }^{15}$

Abbreviations: ER, extended release; IR, immediate release.

distortion of treatment effectiveness ${ }^{28}$ as well as increased health care expenditure. ${ }^{29,30}$ The reasons for noncompliance are manifold and include fear of side effects, complex drug regimens incompatible with everyday life, and dementia. In one study, poorer compliance was identified to be more likely among younger patients and those with complex drug regimens, depression, and lower quality of life. ${ }^{26}$ Grosset et al demonstrated an inverse correlation of compliance and drug doses per day in PD patients ${ }^{31}$ and showed that low therapy adherence was significantly associated with poor motor scores (UPDRS), more days absent from work, and worse mobility (PDQ39). ${ }^{31}$ In this study, all measures of therapy adherence (total number of days adherent, timing adherence, and total therapy adherence) were significantly higher for once-daily medications, including DAs taken once versus three times daily. ${ }^{31}$ Therefore, the availability of once-daily formulations of DAs with established efficacy in PD represents an advantage even if there is no added benefit of enhanced clinical efficacy or safety. In addition, from the patient perspective there is the obvious advantage in terms of convenience and ease of use, particularly in early disease where monotherapy with a single dose per day is possible. Due to blinding purposes, the possible beneficial effects of a once-daily formulation on convenience and adherence have not been possible to assess in the Phase III trials. ${ }^{17,18,20,32}$ ER formulations of a long-acting DA such as pramipexole may also contribute to improved symptom control during the night, although this has not been formally studied to date and is more relevant to advanced rather than early PD. Furthermore, there is a possibility that the pharmacokinetic profile of a slow-release formulation may reduce the risk of peripheral dopaminergic side effects such as nausea and vomiting as well as central adverse reactions, including somnolence and daytime sleepiness, by avoiding rapid plasma level increases and high peak concentrations as compared with their IR counterparts. This has, however, not been demonstrated in the pivotal clinical trials with pramipexole ER.

\section{Conclusion}

Pramipexole is widely established as a symptomatic treatment in early as well as advanced PD. The development of an ER formulation, with stable pramipexole plasma concentration over 24 hours, now offers a bioequivalent once-daily alternative. Double-blind randomized controlled trials in early as well as advanced PD have established the noninferiority of pramipexole ER compared with IR as well as the superiority of both formulations over placebo. The overnight switch from the standard to the once-daily formulation was shown to be successful in $>80 \%$ of patients without requiring any dose adjustments. Potential benefits of prolonged-release once-daily DA formulations include improved compliance and a potential for better symptomatic control over the day as well as during the night. However, the latter, along with reduced risk of dopaminergic side effects, has not been formally demonstrated in the pivotal trial program. From a patient perspective there is little doubt that once-daily drugs offer major advantages in terms of convenience, especially for initial monotherapy in early PD.

\section{Disclosure}

Klaus Seppi has received honoraria for speaking and/or consulting from: Novartis, AstraZeneca, Boehringer Ingelheim, Lundbeck, Schwarz Pharma, UCB Pharma, Teva, and GlaxoSmithKline, and grants/research funding from: The Movement Disorders Society, Michael J Fox Foundation for Parkinson's Research, Österreichische Nationalbank, Austrian Science Fund, and Medical University Innsbruck. Werner Poewe has received consultancy and lecture fees from: AstraZeneca, Teva, Novartis, GlaxoSmithKline, Boehringer-Ingelheim, UCB, Orion Pharma, and Merck Serono in relation to clinical drug development programs for PD, and grants/research funding from: The Movement Disorders Society, Michael J Fox Foundation for Parkinson's Research, Österreichische Nationalbank, Austrian Science Fund, and Medical University Innsbruck. The authors have no other relevant affiliations or financial involvement with any organization or entity with a financial interest in, or financial conflict with, the subject matter or materials discussed in the manuscript apart from those disclosed. No writing assistance was utilized in the production of this manuscript.

\section{References}

1. Olanow C, Agid Y, Mizuno Y, et al. Levodopa in the treatment of Parkinson's disease: current controversies. Mov Disord. 2004;19(9): 997-1005.

2. Holloway R, Shoulson I, Fahn S, et al. Pramipexole vs levodopa as initial treatment for Parkinson disease: a 4-year randomized controlled trial. Arch Neurol. 2004;61(7):1044-1053. 
3. Gerfen C, Engber T, Mahan L, et al. D1 and D2 dopamine receptorregulated gene expression of striatonigral and striatopallidal neurons. Science. 1990;250(4986):1429-1432.

4. Herrero M, Augood S, Hirsch E, et al. Effects of L-DOPA on preproenkephalin and preprotachykinin gene expression in the MPTP-treated monkey striatum. Neuroscience. 1995;68(4):1189-1198.

5. Jolkkonen J, Jenner P, Marsden C. L-DOPA reverses altered gene expression of substance $\mathrm{P}$ but not enkephalin in the caudate-putamen of common marmosets treated with MPTP. Brain Res Mol Brain Res. 1995;32(2):297-307.

6. Antonini A, Tolosa E, Mizuno Y, Yamamoto M, Poewe WH. A reassessment of risks and benefits of dopamine agonists in Parkinson's disease. Lancet Neurol. 2009;8(10):929-937.

7. Antonini A, Poewe W. Fibrotic heart-valve reactions to dopamine-agonist treatment in Parkinson's disease. Lancet Neurol. 2007;6(9):826-829.

8. Rascol O, Brooks D, Korczyn A, De Deyn P, Clarke C, Lang A. A five-year study of the incidence of dyskinesia in patients with early Parkinson's disease who were treated with ropinirole or levodopa. 056 Study Group. N Engl J Med. 2000;342(20):1484-1491.

9. Group PS. Pramipexole vs levodopa as initial treatment for Parkinson disease: A randomized controlled trial. Parkinson Study Group. JAMA. 2000;284(15):1931-1938.

10. Oertel W, Wolters E, Sampaio C, et al. Pergolide versus levodopa monotherapy in early Parkinson's disease patients: The PELMOPET study. Mov Disord. 2006;21(3):343-353.

11. Horstink M, Tolosa E, Bonuccelli U, et al. Review of the therapeutic management of Parkinson's disease. Report of a joint task force of the European Federation of Neurological Societies (EFNS) and the Movement Disorder Society-European Section (MDS-ES). Part II: late (complicated) Parkinson's disease. Eur J Neurol. 2006;13(11):1186-1202.

12. Miyasaki JM, Martin W, Suchowersky O, Weiner WJ, Lang AE. Practice parameter: initiation of treatment for Parkinson's disease: an evidence-based review: report of the Quality Standards Subcommittee of the American Academy of Neurology. Neurology. 2002;58(1):11-17.

13. Gerlach M, Double K, Arzberger T, Leblhuber F, Tatschner T, Riederer P. Dopamine receptor agonists in current clinical use: comparative dopamine receptor binding profiles defined in the human striatum. J Neural Transm. 2003;110:1119-1127.

14. Kohno Y, Takeuchi S. Pharmacological profiles and clinical effects of antiparkinsonian agent, pramipexole. Nihon Yakurigaku Zasshi. 2004;123(6):429-440.

15. European Medicines Agency. Assessment Report for Sifrol. EMEA/703892/2009. London: European Medicines Agency; 2009. Available from: http://www.ema.europa.eu/docs/en_GB/document_ library/EPAR_-_Assessment_Report_-_Variation/human/000133/ WC500049957.pdf. Accessed August 9, 2010.

16. Jenner P, Könen-Bergmann M, Schepers C, Haertter S. Pharmacokinetics of a once-daily extended-release formulation of pramipexole in healthy male volunteers: three studies. Clin Ther. 2009;31(11):2698-2711.
17. Poewe W, Rascol O, Barone P, et al. Extended-release pramipexole in early Parkinson disease: A 33-week randomized controlled trial. Neurology. 2011;77:759-766.

18. Hauser RA, Schapira AH, Rascol O, et al. Randomized, double-blind, multicenter evaluation of pramipexole extended release once daily in early Parkinson's disease. Mov Disord. 2010;25(15):2542-2549.

19. Schrag A, Spottke A, Quinn N, Dodel R. Comparative responsiveness of Parkinson's disease scales to change over time. Mov Disord. 2009;24(6):813-818.

20. Rascol O, Barone P, Hauser RA, et al. Efficacy, safety, and tolerability of overnight switching from immediate- to once daily extendedrelease pramipexole in early Parkinson's disease. Mov Disord. 2010;25(14):2326-2332.

21. Viller F, Guillemin F, Briançon S, Moum T, Suurmeijer T, van den Heuvel W. Compliance to drug treatment of patients with rheumatoid arthritis: a 3 year longitudinal study. J Rheumatol. 1999;26(10):2114-2122.

22. Cramer J, Vachon L, Desforges C, Sussman NM. Dose frequency and dose interval compliance with multiple antiepileptic medications during a controlled clinical trial. Epilepsia. 1995;36(11):1111-1117.

23. Cramer JA. A systematic review of adherence with medications for diabetes. Diabetes Care. 2004;27(5):1218-1224.

24. Sackett DL, Haynes RB, Gibson ES, Taylor DW, Roberts RS, Johnson AL. Patient compliance with antihypertensive regimens. Patient Couns Health Educ. 1978;1(1):18-21.

25. Leopold NA, Polansky M, Hurka MR. Drug adherence in Parkinson's disease. Mov Disord. 2004;19(5):513-517.

26. Grosset KA, Bone I, Grosset DG. Suboptimal medication adherence in Parkinson's disease. Mov Disord. 2005;20(11):1502-1507.

27. Grosset KA, Reid JL, Grosset DG. Medicine-taking behavior: implications of suboptimal compliance in Parkinson's disease. Mov Disord. 2005;20(11):1397-1404.

28. Haynes RB, Dantes R. Patient compliance and the conduct and interpretation of therapeutic trials. Control Clin Trials. 1987;8(1):12-19.

29. Richter A, Anton SE, Koch P, Dennett SL. The impact of reducing dose frequency on health outcomes. Clin Ther. 2003;25(8):2307-2335; discussion 2306.

30. Davis KL, Edin HM, Allen JK. Prevalence and cost of medication nonadherence in Parkinson's disease: evidence from administrative claims data. Mov Disord. 2010;25(4):474-480.

31. Grosset D, Antonini A, Canesi M, et al. Adherence to antiparkinson medication in a multicenter European study. Mov Disord. 2009;24(6):826-832.

32. Schapira AH, Barone P, Hauser RA, et al. Extended-release pramipexole in advanced Parkinson disease: a randomized controlled trial. Neurology. 2011;77(8):767-774.
Clinical Interventions in Aging

\section{Publish your work in this journal}

Clinical Interventions in Aging is an international, peer-reviewed journal focusing on evidence-based reports on the value or lack thereof of treatments intended to prevent or delay the onset of maladaptive correlates of aging in human beings. This journal is indexed on PubMed Central, MedLine, the American Chemical Society's 'Chemical Abstracts

\section{Dovepress}

Service' (CAS), Scopus and the Elsevier Bibliographic databases. The manuscript management system is completely online and includes a very quick and fair peer-review system, which is all easy to use. Visit http://www.dovepress.com/testimonials.php to read real quotes from published authors. 